\title{
Isolation of Extrachromosomal Deoxyribonucleic Acids from Extremely Thermophilic Bacteria
}

\author{
BY FUMIO HISHINUMA, TERUO TANAKA \\ AND KENJI SAKAGUCHI \\ Mitsubishi Kasei Institute of Life Sciences, Laboratory of Microbiological Chemistry, \\ 11 Minamiooya, Machida-shi, Tokyo, Japan 194
}

(Received 2 August 1977; revised 29 September 1977)

\begin{abstract}
Eight strains of thermophilic bacteria were examined for the presence of covalently closed circular deoxyribonucleic acid molecules by caesium chloride-ethidium bromide density gradient centrifugation. Four of the eight strains tested, Thermus flavus Bs1, AT61, AT62 and Thermus thermophilus HB8 carried covalently closed circular DNA molecules. Thermus flavus BS1 harboured two species of plasmids with molecular weights of $6.1 \times 10^{6}$ and $17.0 \times 10^{6}$ as determined by electron microscopy. Thermus thermophilus HB8, T. flavus AT61 and $T$. flavus AT62 carried plasmids with molecular weights of $6.2 \times 10^{6}, 6.6 \times 10^{6}$ and $6.6 \times$ $10^{6}$, respectively. Plasmids from T. flavus AT61 and AT62 were indistinguishable in their electrophoretic patterns in agarose or acrylamide gel after digestion with various restriction endonucleases. This is the first evidence for the presence of plasmids in extremely thermophilic bacteria, though their functions are unknown.
\end{abstract}

\section{INTRODUCTION}

Recently, techniques for introducing recombinant DNA molecules into Escherichia coli cells as autonomous replicons have been developed (Cohen, 1975). The use of these techniques has been of major importance in the advance of fundamental knowledge, and has already contributed to our understanding of the structure and function of genes (Cohen \& Chang, 1975; Cohn, Lowry \& Kedes, 1976; Efstratiadis, Kafatos \& Maniatis, 1977; Brutlag et al., 1977; Hershey et al., 1977; Tonegawa et al., 1977). At the same time, there has been concern over potential biohazards and attention has focused upon the need for DNA cloning vectors and bacterial hosts with a restricted capacity to multiply and transmit genetic information outside the laboratory.

The establishment of in vitro recombinant DNA techniques in an extreme thermophile should reduce the risks since these bacteria are obligate aerobes, are not parasitic, not sporeforming, and grow only above $45^{\circ} \mathrm{C}$ with an optimum growth temperature of 60 to $72{ }^{\circ} \mathrm{C}$ (Oshima \& Imahori, 1971; Saiki, Kimura \& Arima, 1972). Furthermore, Lindsay \& Creaser (1975) reported that thermostability of an enzyme was a transformable property between Bacillus species. It would be of interest to test whether genes from mesophilic bacteria could function in the thermophiles and if they do, whether products of the genes are converted to heat resistance.

We have looked for plasmids which would serve as vectors for the construction of recombinant DNA molecules in extreme thermophiles. This report describes the demonstration of covalently closed circular (CCC) DNA molecules in four Thermus strains by the technique of $\mathrm{CsCl}-$ ethidium bromide density gradient centrifugation. The isolation and characterization of these plasmids is reported. 


\section{METHODS}

Bacterial strains and growth conditions. Thermophilic bacteria were kindly supplied by Dr T. Oshima of this Institute. The extreme thermophiles, Thermus thermophilus HB8 (Oshima \& Imahori, 1971), Thermus HB27 (Sakaki \& Oshima, 1975), and Thermus flavus strains Bs1, BK1, AT61 and AT62 (Saiki et al., 1972), were cultured at $75^{\circ} \mathrm{C}$ with shaking in nutrient broth (pH 7.0) containing $\left(\mathrm{g} \mathrm{l}^{-1}\right)$ : polypeptone (Daigo Eiyo Chemical Co., Osaka, Japan), 5; yeast extract (Difco), 4; $\mathrm{NaCl}, 2$; and glucose, 1 (Hishinuma, Hirai \& Sakaguchi, 1977). A moderate thermophile, Bacillus stearothermophilus IAM1035 was grown at $60^{\circ} \mathrm{C}$ in a medium consisting of $\left(\mathrm{g}^{-1}\right)$ : yeast extract, 5; polypeptone, $5 ; \mathrm{K}_{2} \mathrm{HPO}_{4}, 1$; and glucose, 2 . An acidophilic and thermophilic bacterium, Bacillus acidocardarius TA6, was grown at $65^{\circ} \mathrm{C}$ in the medium described by Oshima, Arakawa \& Baba (1977).

Isolation of plasmids. Methods for the isolation of CCC DNA from the bacteria and the isotopic labelling of DNA were as described previously for the isolation of plasmids from Bacillus subtilis (Tanaka, Kuroda \& Sakaguchi, 1977) except that the initial density of the $\mathrm{CsCl}$-ethidium bromide solution was adjusted to $1.600 \mathrm{~g} \mathrm{ml}^{-1}$ and $\left[{ }^{3} \mathrm{H}\right.$ ]adenosine $\left(10 \mu \mathrm{Ci} \mathrm{ml}^{-1}\right.$; The Radiochemical Centre, Amersham) was used instead of $\left[{ }^{3} \mathrm{H}\right]$ thymidine since thymidine was not incorporated into the DNA of the extreme thermophiles even when deoxyadenosine was present in the culture medium. Plasmid DNA was collected from the gradient, extracted three times with 1 vol. $n$-butanol to remove ethidium bromide, and dialysed against $0 \cdot 1 \times$ SSC (SSC buffer is $0.15 \mathrm{M}$-sodium chloride/0.015 $\mathrm{M}$-sodium citrate) plus $1 \mathrm{~mm}$-EDTA. The plasmid DNA preparation was incubated with ribonuclease $\mathrm{A}\left(10 \mu \mathrm{g} \mathrm{ml}^{-1}\right.$; Sigma) and ribonuclease $\mathrm{T} 1$ (5 $\mu \mathrm{g} \mathrm{ml}^{-1}$; Sankyo Co., Tokyo, Japan) to digest the ribonucleic acids.

Sucrose density gradient centrifugation. ${ }^{3} \mathrm{H}$-labelled plasmid DNAs were centrifuged in neutral 5 to $20 \%$ (w/v) linear sucrose gradients in buffer consisting of $0.03 \mathrm{M}$-Tris/HCl pH 8.0, 0.005 $\mathrm{M}$-EDTA and $1 \mathrm{M}-\mathrm{NaCl}$. ${ }^{14} \mathrm{C}$-Labelled $\lambda$ phage DNA (obtained by heat induction of $E$. coli $\mathrm{M} 65$ lysogenized with $\lambda$ cI857S7) was added to each sample as an internal marker for measuring $\mathbf{S}$ values of the plasmids. The samples were centrifuged at $50000 \mathrm{rev} . \mathrm{min}^{-1}$ for $90 \mathrm{~min}$ in a Hitachi RPS65T rotor. Gradients were fractionated, and $0 \cdot 1 \mathrm{ml}$ portions of each fraction were applied to Whatman GF/C filters, dried and counted in a liquid scintillation counter.

Determination of the molecular weights of plasmid DNA by agarose gel electrophoresis. Plasmid DNAs were incubated with freshly diluted deoxyribonuclease I (0.01 $\mu \mathrm{g} \mathrm{m}^{-1}$; Worthington Biochemical Corp.) for $10 \mathrm{~min}$ at $20^{\circ} \mathrm{C}$ in $10 \mathrm{~mm}$-Tris/ $\mathrm{HCl} \mathrm{pH} 8.0$ containing $5 \mathrm{~mm}-\mathrm{MgCl}_{2}$ and $20 \mathrm{~mm}-\mathrm{NaCl}$. The reaction was stopped by addition of 0.033 vol. 0.5 M-EDTA (pH 8.0). Approximately $80 \%$ of the plasmid molecules were converted to the linear form by this treatment; the remaining $20 \%$ were in the open circular form. The incubated mixture was added to EcoRI digests of $\lambda$ phage DNA, RSF1010 DNA [mol. wt 5.5 $\times 10^{6}$ (Tanaka \& Weisblum, 1975)] and RSF2124 DNA [mol. wt 7.2 $\times 10^{6}$ (So, Gill \& Falkow, 1975)] as internal markers, and the samples were electrophoresed in $0.7 \%(\mathrm{w} / \mathrm{v})$ agarose gels.

Electron microscopy. The procedure has been described previously (Tanaka et al., 1977). The electron microscope used was model JEOL-100B (JEOL, Tokyo, Japan). The molecular weight of each plasmid was determined by comparison with ColE1 DNA $\left[4 \cdot 2 \times 10^{6}\right.$ (Bazaral \& Helinski, 1968)] added as an internal standard.

Digestion of plasmid DNAs with restriction endonucleases. Plasmid DNAs were digested with restriction endonucleases EcoRI (Tanaka \& Weisblum, 1975), HindIII (Smith \& Wilcox, 1970), HpaI (Sharp, Sugden \& Sambrook, 1973), HindII (Landy et al., 1974), BamNI (identical with BamI) (Shibata \& Ando, 1976) and SmaR (Tanaka \& Weisblum, 1975) for $30 \mathrm{~min}$ at $37^{\circ} \mathrm{C}$, and heated at $65^{\circ} \mathrm{C}$ for 5 min to inactivate the enzymes. The resultant DNA fragments were separated by electrophoresis in agarose or acrylamide gels. Gels were formed in an electrophoretic buffer ( $\mathrm{pH} \mathrm{8.0)}$ consisting of 40 mM-Tris base, 20 mM-sodium acetate, $1 \mathrm{mM}$-EDTA and $0.5 \mu \mathrm{g}$ ethidium bromide $\mathrm{ml}^{-1}$.

\section{RESULTS}

\section{Isolation of plasmids}

Four of the eight thermophiles tested, $T$. thermophilus HB8, and T. flavus AT61, AT62 and Bs1, harboured plasmids. For quantitative analysis, cells were labelled with $\left[{ }^{3} \mathrm{H}\right]$ adenosine and the whole lysates were centrifuged in $\mathrm{CsCl}$-ethidium bromide gradients. Satellite peaks were observed in these four strains to an extent of $1.9 \%, 1.2 \%, 2.0 \%$ and $2.8 \%$ of the chromosomal DNA, respectively. 


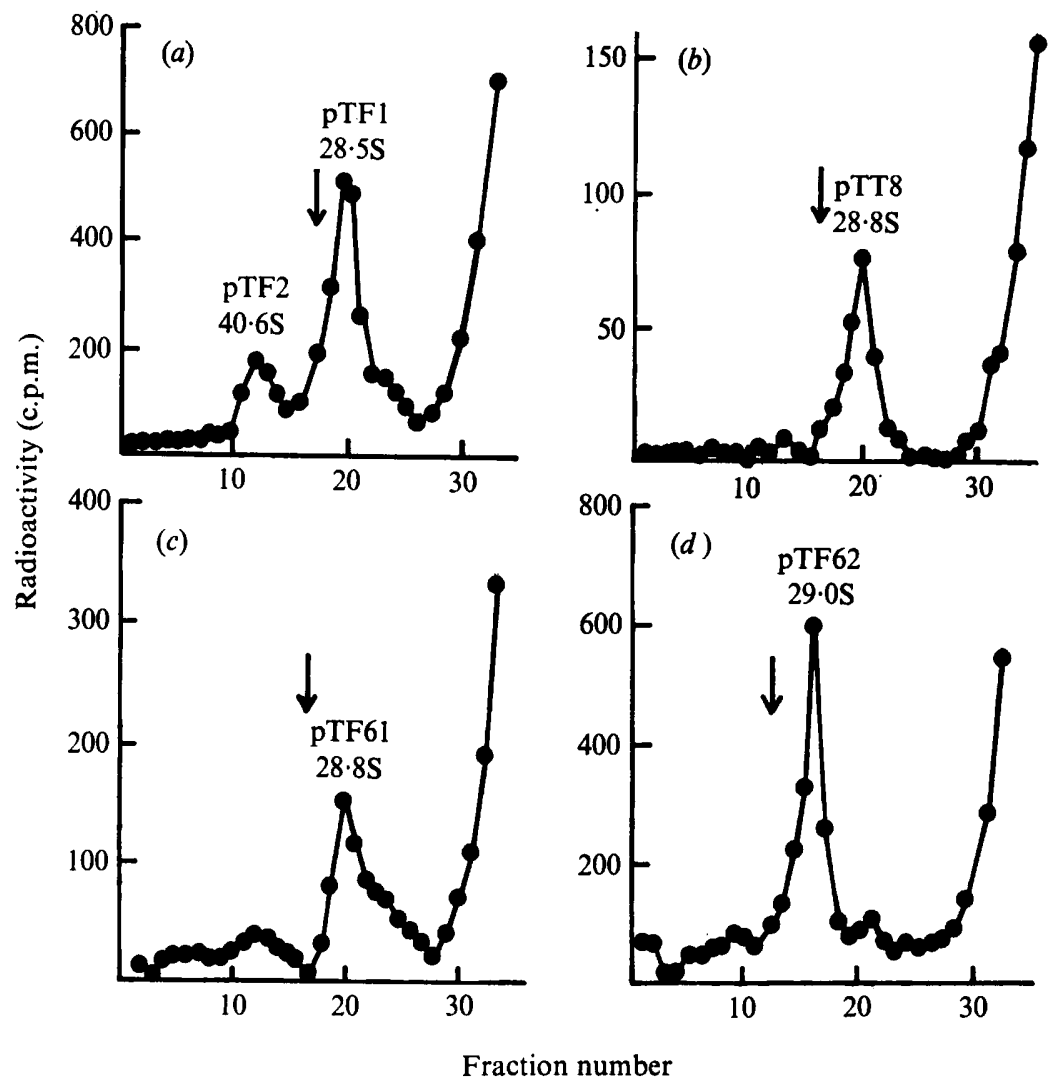

Fig. 1. Sucrose density gradient centrifugation ( 5 to $20 \%, \mathrm{w} / \mathrm{v})$ of [ $\left.{ }^{\mathrm{s}} \mathrm{H}\right]$ adenosine-labelled plasmid DNA from: (a) T. flavus BS1; (b) T. thermophilus HB8; (c) T. flavus AT61; (d) T. flavus AT62. Plasmid DNAs were labelled as described in Methods. Arrows indicate the position of $\left.{ }^{[14} \mathrm{C}\right]$ thymidine-labelled $\lambda$ DNA included as a molecular weight marker. The top of the gradient is to the right. The radioactivity in the top of each gradient is due to small fragments of RNA generated by RNAase A and RNAase $\mathrm{T} 1$ treatment.

\section{Sucrose density gradient centrifugation}

The ${ }^{3} \mathrm{H}$-labelled plasmid DNAs obtained from the $\mathrm{CsCl}$-ethidium bromide density gradients were subjected to neutral 5 to $20 \%(\mathrm{w} / \mathrm{v})$ sucrose density gradient centrifugation with ${ }^{14} \mathrm{C}$-labelled $\lambda$ DNA as a marker (33.6S) for determination of molecular weight. The gradient from $T$. flavus BS1 gave two peaks with S values of 28.5 and 40.6 (Fig. $1 a$ ) indicating that there are two plasmids (pTF1 and pTF2, respectively) in the cell. Plasmids of $T$. thermophilus HB8, and T. flavus AT61 and AT62 sedimented at 28.8S (pTT8), 28.8S (pTF61) and 29.0S (pTF62), respectively (Fig. $1 b$ to $d$ ). The molecular weights of these plasmids, as calculated by the equation of Hudson, Clayton \& Vinograd (1968), are presented in Table 1.

The number of copies of each plasmid can be calculated from the molecular weight and the amount of plasmid present in the $\mathrm{CCC}$ form per chromosome. On the assumption that the molecular weight of the chromosomal DNA of these extreme thermophiles is the same as that of $E$. coli $\left[2.5 \times 10^{9}\right.$ (Cooper \& Helmstetter, 1968)] and that most of the plasmids are obtained in the $\mathrm{CCC}$ form, the numbers of copies were estimated and are summarized in Table 1. 

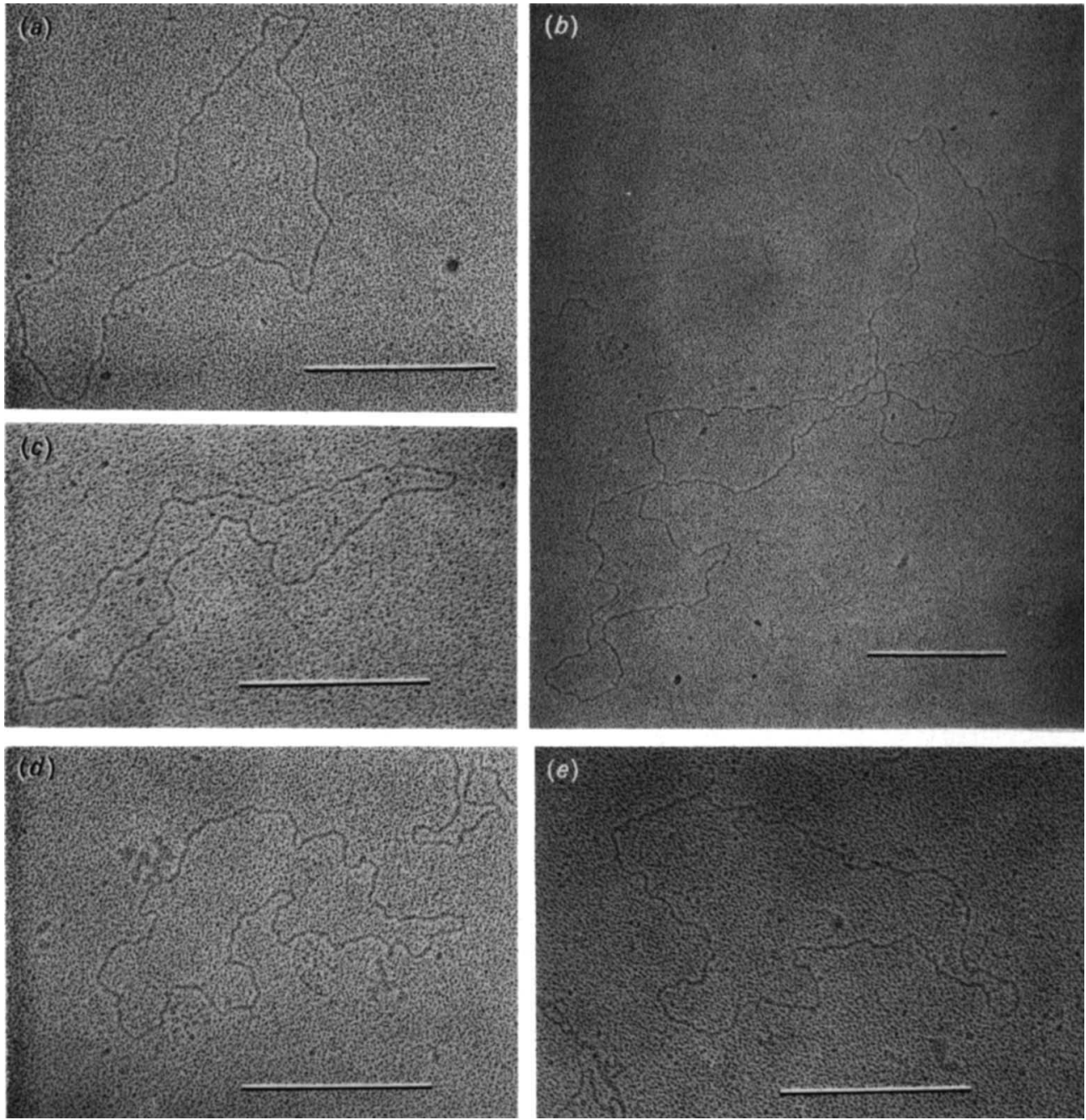

Fig. 2. Electron micrographs of circular plasmid DNA: (a) pTF1; (b) pTF2; (c) pTT8; (d) pTF61; (e) pTF62. Bar markers correspond to a mol. wt of $1.0 \times 10^{6}$.

Table 1. Molecular weights and number of copies of the plasmids from extreme thermophiles $10^{-6} \times$ mol. wt, determined by:

Strain $\quad$ Plasmid $\quad \overbrace{\begin{array}{c}\text { Sucrose } \\ \text { gradient } \\ \text { centri- } \\ \text { fugation* }\end{array}}^{\begin{array}{c}\text { Agarose gel } \\ \text { electro- } \\ \text { phoresis } \dagger\end{array}} \begin{gathered}\begin{array}{c}\text { Electron } \\ \text { microscopy } \ddagger \text { per chromosoms }\end{array} \\ \text { No. of copies }\end{gathered}$

T. flavus Bs1
T. flavus Bs1
T. thermophilus HB8
T. flavus AT61
$T$. flavus AT62

pTF1
pTF2
pTT8
pTF61
pTF62

$6 \cdot 2$
$13 \cdot 5$
$6 \cdot 3$
$6 \cdot 3$
$6 \cdot 4$

$5 \cdot 9$
$-\S$
$5 \cdot 9$
6.6
6.6

* $\lambda$ DNA was included as an internal marker.

$\dagger$ Linear plasmid DNAs were obtained by digestion with deoxyribonuclease I as described in Methods, and electrophoresed with EcoRI digests of $\lambda$ DNA, RSF1010 and RSF2124 as internal standards.

$\ddagger$ ColE1 DNA was used as an internal standard.

$\S$ The molecular weight of pTF2 was estimated to be larger than $13.7 \times 10^{6}$ (the largest fragment of EcoRI digests of $\lambda$ DNA) and was not determined by this method. 
Table 2. Number of cleavage sites with restriction endonucleases

Plasmid DNAs were digested with restriction endonucleases for $30 \mathrm{~min}$ at $37^{\circ} \mathrm{C}$, heated at $65^{\circ} \mathrm{C}$ for $5 \mathrm{~min}$, and the resultant fragments were separated by electrophoresis in agarose (digests with EcoRI, HindIII, HpaI, and HindII) or acrylamide (digests with BamNI and SmaR) gels.

\begin{tabular}{lcccc} 
& \multicolumn{4}{c}{ No. of cleavage sites } \\
Enzyme & pTF1 & pTT8 & pTF61 & pTF62 \\
EcoRI & 0 & 0 & 0 & 0 \\
HindIII & 0 & 0 & 2 & 2 \\
Bam NI & 5 & 11 & 9 & 9 \\
SmaR & 16 & 10 & 12 & 12 \\
HpaI & 0 & 1 & 1 & 1 \\
HindII & 0 & 5 & 2 & 2
\end{tabular}

(a) (b) (c) (d)

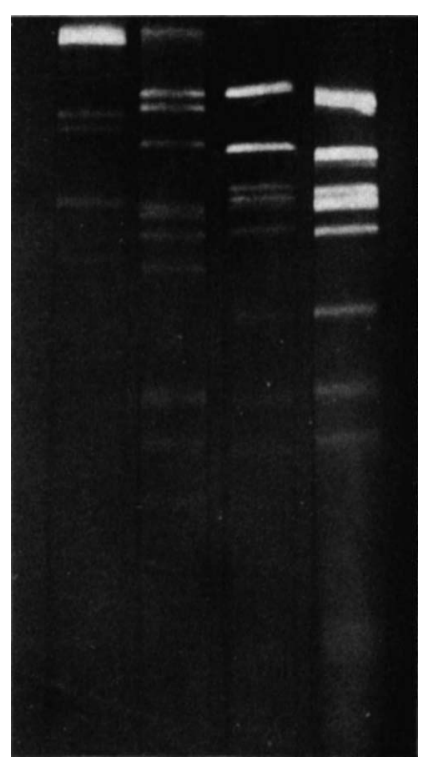

(a)

(b) (c)

(d)

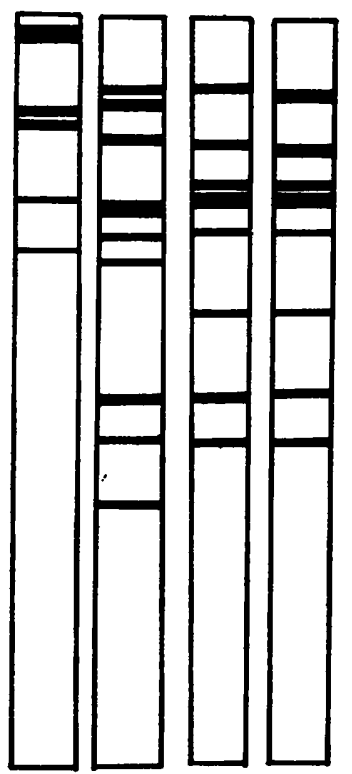

Fig. 3. Cleavage patterns of plasmid DNAs with BamNI restriction endonuclease. Digests were fractionated by electrophoresis in $5 \%(\mathrm{w} / \mathrm{v})$ acrylamide gels. (a) Mixed sample of pTF1 and pTF2; (b) pTT8; (c) pTF61; (d) pTF62. DNA fragments from pTF61 and pTF62 were superimposable when electrophoresed in one tube (data not shown).

\section{Determination of molecular weights of plasmids}

The linear forms of plasmid DNAs were electrophoresed in agarose gels with internal markers to determine their molecular weights (Table 1). Each plasmid was further examined by electron microscopy. Twisted molecules were observed in plasmid samples, and they were converted to open circular forms during storage for more than 1 month at $4{ }^{\circ} \mathrm{C}$ or upon nicking with $1 \mathrm{ng}$ deoxyribonuclease $\mathrm{I} \mathrm{ml}^{-1}$ (Fig. $2 a$ to $e$ ). With added ColE1 DNA (mol. wt $4.2 \times 10^{6}$ ) as an internal standard, molecular weights of the five plasmids were determined (Table 1).

\section{Digestion with restriction endonucleases}

The number of cleavage sites after restriction enzyme digestion are summarized in Table 2. pTF61 and pTF62 were indistinguishable in their molecular weights (Table 1), in the number of cleavage sites with five restriction endonucleases (Table 2), and in the electrophoretic pattern of the small fragments generated by SmaR or BamNI digestion (Fig. 3). 


\section{Properties of the plasmid-harbouring strains}

The plasmid-harbouring strains did not show resistance to ampicillin, streptomycin, kanamycin, tetracycline, or chloramphenicol at $10 \mu \mathrm{g} \mathrm{ml}^{-1}$. The ability to produce bacteriocins was examined by the double-layer technique of Fredericq (1957), using six extreme thermophiles as indicators. No clear zone was observed around the colonies of the six strains, indicating that the presence of plasmids could not be correlated with bacteriocin production. The six extreme thermophiles used in this study had a common biological nature: yellow-pigmented, heterotrophic and optimum growth at 60 to $72{ }^{\circ} \mathrm{C}$. The biological functions specified by these plasmids have not been identified so far.

\section{DISCUSSION}

This paper describes the isolation and characterization of five plasmids from extremely thermophilic bacteria isolated from hot springs in Japan. Thermus flavus AT61 and AT62 carried indistinguishable plasmids as determined by their molecular weights and cleavage patterns with restriction endonucleases, though the two strains were different in their phage susceptibility. Bacteriophage YS40 isolated by Sakaki \& Oshima (1975) infects T. thermophilus HB8 and $T$. flavus AT61, but not $T$. flavus AT62 (Sakaki \& Oshima, 1975). These observations suggest that pTF61 (pTF62) was transferred by some mechanism from one strain to another, although we cannot rule out the possibility that one of the two strains mutated in terms of phage host-specificity.

The plasmids from the extreme thermophiles were not cleaved by EcoRI and were more sensitive to BamNI and SmaR which cleave sites with the sequence GGATCC (Shibata \& Ando, 1976) and CCCGGG (McParland, Brown \& Pearson, 1976), respectively. This suggests that the plasmid DNAs have high deoxyguanosine and deoxycytosine contents like their chromosomal DNA (69 to 70\%) (Oshima \& Imahori, 1971; Saiki et al., 1972).

The large plasmid (pTF2) was present as only a single copy, whereas there were many copies of the small plasmids (pTF1, pTT8, pTF61 and pTF62). The fact that the latter plasmids were small and that there were many copies of them should facilitate molecular cloning in extreme thermophiles.

We are grateful to Drs T. Oshima and K. Nagahari for helpful discussions, and to Miss T. Koshikawa for technical assistance.

\section{REFERENCES}

Bazaral, M. \& Helinski, D. R. (1968). Circular DNA of colicinogenic factors $E_{1}, E_{2}$ and $E_{3}$ from Escherichia coli. Journal of Molecular Biology 36, 185-194.

Brutlag, D., Fry, K., Nelson, T. \& Hung, P. (1977). Synthesis of hybrid bacterial plasmids containing highly repeated satellite DNA. Cell 10, 509-519.

COHEN, S. N. (1975). The manipulation of genes. Scientific American 233, 24-33.

Cohen, S. N. \& Chang, A. C. Y. (1975). Transformation of Escherichia coli by plasmid chimeras constructed in vitro: a review. In Microbiology1974, pp. 66-75. Edited by D. Schlessinger. Washington, D.C.: American Society for Microbiology.

Cohn, R. H., Lowry, J. C. \& Kedes, L. H. (1976). Histone genes of the sea urchin ( $S$. purpuratus) cloned in $E$. coli : order, polarity, and strandedness of the five histone-coding and spacer regions. Cell 9, 147-161.

CoOper, S. \& Helmstetter, C. (1968). Chromosome replication and the division cycle of Escherichia coli $\mathrm{B} / \mathrm{r}$. Journal of Molecular Biology 31, 519-540.

Efstratiadis, A., Kafatos, F. C. \& Maniatis, T. (1977). The primary structure of rabbit $\beta$-globin mRNA as determined from cloned DNA. Cell 10, 571-585.

FredericQ, P. (1957). Colicins. Annual Review of Microbiology 11, 7-22.

Hershey, N. D., Conrad, S. E., Sodja, A., Yen, P. H., Cohen, M., JR, Davidson, N., Ilgen, C. \& CARBon, J. (1977). The sequence arrangement of Drosophila melanogaster 5S DNA cloned in recombinant plasmids. Cell 11, 585-598.

Hishinuma, F., Hirai, K. \& Sakaguchi, K. (1977). 
Thermophilic polynucleotide phosphorylase from Thermus thermophilus. Purification and properties of an altered form enzyme which lacks phosphorolytic activity to polynucleotide. European Journal of Biochemistry 77, 575-583.

Hudson, B., Clayton, D. A. \& Vinograd, J. (1968). Complex mitochondrial DNA. Cold Spring Harbor Symposia on Quantitative Biology 28, 435-442.

LANDy, A., Ruedisueli, E., Robinson, L., FoelleR, C. \& Ross, W. (1974). Digestion of deoxyribonucleic acids from bacteriophage $\mathrm{T} 7, \lambda$, and $\phi 80 \mathrm{~h}$ with site-specific nucleases from Hemophilus influenzae strain Rc and strain Rd. Biochemistry 13, 2134-2142.

Lindsay, J. A. \& Creaser, E. H. (1975). Enzyme thermostability is a transformable property between Bacillus spp. Nature, London 255, 650-652.

McParland, R. H., Brown, L. R. \& Pearson, G. D. (1976). Cleavage of $\lambda$ DNA by a sitespecific endonuclease from Serratia marcescens. Journal of Virology 19, 1006-1011.

OshIMA, T. \& IMAHORI, K. (1971). Isolation of an extreme thermophile and thermostability of its transfer ribonucleic acid and ribosomes. Journal of General and Applied Microbiology 17, 513-517.

Oshima, T., Arakawa, H. \& Baba, M. (1977). Biochemical studies on an acidophilic, thermophilic bacterium, Bacillus acidocardarius: isolation of bacteria, intracellular $\mathrm{pH}$, and stabilities of biopolymers. Journal of Biochemistry 81, 1107-1113.

SAIKI, T., KImURA, R. \& ARIMA, K. (1972). Isolation and characterization of extremely thermophilic bacteria from hot springs. Agricultural and Biological Chemistry 36, 2357-2366.
SAKAKI, Y. \& OsHmMA, T. (1975). Isolation and characterization of a bacteriophage infectious to an extreme thermophile, Thermus thermophilus HB8. Journal of Virology 15, 1449-1453.

Sharp, P. A., Sugden, B. \& Sambrook, J. (1973). Detection of two restriction endonuclease activities in Haemophilus parainfluenzae using analytical agarose-ethidium bromide electrophoresis. Biochemistry 12, 3055-3063.

Shibata, T. \& ANDO, T. (1976). The restriction endonuclease in Bacillus amyloliquefaciens $\mathbf{N}$ strain. Substrate specificities. Biochimica et biophysica acta 442, 184-196.

SмITH, H. O. \& WILcox, K. W. (1970). A restriction enzyme from Hemophilus influenzae. I. Purification and general properties. Journal of Molecular Biology 51, 379-391.

So, M., Gill, R. \& Falkow, S. (1975). The generation of a ColE1-Ap ${ }^{x}$ cloning vehicle which allows detection of inserted DNA. Molecular and General Genetics 142, 239-249.

TANAKa, T. \& WeisBlum, B. (1975). Construction of a colicin E1-R factor composite plasmid in vitro: means for amplification of deoxyribonucleic acid. Journal of Bacteriology 121, 354-362.

Tanaka, T., Kuroda, M. \& Sakaguchi, K. (1977). Isolation and characterization of four plasmids from Bacillis subtilis. Journal of Bacteriology 129, 1487-1494.

Tonegawa, S., Brack, C., Hozumi, N. \& Schuller, R. (1977). Cloning of an immunoglobulin variable region gene from mouse embryo. Proceedings of the National Academy of Sciences of the United States of America 74, 3518-3522. 